\title{
GRAPHOMOTOR SKILLS IN CHILDREN WITH LANGUAGE DEFICITS IN PRIMARY SCHOOL AGE-FORMATION AND DEVELOPMENT
}

\author{
Spassova Kalinka \\ Medical University Varna Prof. Dr Paraskev Stoyanov - Faculty of Public Health, Varna, Bulgaria
}

Primljen/Received 25. 06. 2020. god.

Abstract: Introduction: The formation and the development of graphomotor skills in children with language deficits in primary school age is a difficult and long process, and its disturbance leads to serious problems not only with the process of literation but also disrupt the purely academical learning.

Purpose: The aim of our study is to show the level of formation of graphomotor skills in children with language deficits in primary school age before and after the implementation of a system of therapeutic techniques, approaches and methods based on both the world's and Bulgarian's experience in the area of therapy of disturbance in graphomotor skills.

Material and Method: The study encompasses a total of 40 children in primary school, aged $7-8$, who were subjected to logopedic therapy aimed to overcome difficulties in graphomotor skills. It was conducted for a period of 5 years. The therapy was done either individually or in groups of 2 children.

Results: The data from test 1 and test 2 show development and maturation of structures in the left hemisphere: frontoparietal and basal temporal, responsible for functioning of the spatial orientation and ideomotor apraxia. For this reason the 7-8 years age group can be considered sensible for development of graphomotor skills as a component of formation of the written form of language and is especially suitable for intensive logopedic therapy aimed for its formation.

Conclusion: The implemented therapeutic techniques during the logopedic therapy are aimed not only for establishing the occulo-spacial orientation but also for formation and development of language competence, which are directly linked to formation of the written form of language.

Key words: graphomotor skills, frontopartietal structures, ideomotor apraxia.
Prihvaćen/Accepted 05. 09. 2020. god.

\section{INTRODUCTION}

The formation and development of graphomotor skills in children with language deficits in primary school age is a hard and a long process and its disturbance leads to serious problems not only with the process of literation but also disrupt the purely academical learning. In this particular age the establishment of literacy, as one of the important processes in human life, starts. This process is dependent on the normal development of senses (vision, hearing and touch), intellect and social environment.

The scientific work in this area show that the formation of the written skills is disrupted by disturbance in the visual- motor coordination in children and school pupils as a result of immaturity or false formation of some of the higher cortical functions which are responsible for development of the graphomotor skills and habits. Their disturbed formation leads to aberration in orientation in space and time, low motivation and insufficient self-control, expressed in difficulty in the process of formation of graphomotor skills and mastering the written form of language (1-4).

From psycho- physiological view and based on neuro-psychological model in the process of masteringwritten language three features take part: visual, kinetic and auditory. Historically speaking the leading role has the discovered by Exner "area of writing" in the posterior part of the second frontal gyrus, the so called premotor field or Brodmann area 8 (1-4).

Purpose of our study is to show the level of formation of graphomotor skills in children with language deficits in primary school age (7-8 years) before and after the implementation of a system of therapeutic techniques, approaches and methods based on both the world's and Bulgarian's experience in the area of therapy of disturbance in graphomotor skills. 


\section{MATERIAL AND METHODS}

The study encompasses a total of 40 children in primary school- aged 7-8, who were subjected to logopedic therapy aimed to overcome difficulties in graphomotor skills. It was conducted for a period of 5 years (2012-2017). The implemented therapy was done either individually or in groups of 2 children, in speech therapy center in Varna, Bulgaria.Òhå research has Approval of local Ethical committee and adhered to the principles of the Declaration of Helsinki.

The children, part of this study who were subjected to logopedic therapy, after initial evaluation by a medical board were diagnosed with the following disorders according to ICD-10: F80.9 "Developmental disorder of speech and language, unspecified", F81"Specific reading disorder", F81.3 "Mixed disorder of scholastic skills", F81.8 "Other developmental disorders of scholastic skills. Developmental expressive writing disorder", F81.9 "Developmental disorder of scholastic skills, unspecified" (5).

The number of children in this study was 40 , divided into males M - 19 (47.5\%) and females F - 21 (52.5 $\%)$ (Table 1).

Children from all age groups were evaluated before the initiation of the logopedic therapy with the following tests:

"Head test" (special postural praxis): Aimed for testing ideomotor praxis for new movements. In our study we used a version of the test with 13 movements.

"Test for evaluating written language in children with language deficits in primary school age": The test consists of dictation. The texts used in this experiment were consistent with the age group of the children as well as the National school standards for the particular age group.
Data from the dictation were written in a protocol developed by Yakimova (6) and for a certain number of mistakes an additional evaluation scale was added. The types of mistakes noted in the protocol were grouped in three levels: grapheme, morpheme as well as optically, phonetic-phonematic mistakes and misspellings. The work with the students continued for one year and in the end of the period they are being evaluated again with the described test for the particular age group.

For summarizing the results before initiating logopedic therapy and in the end of the school year the following statistical tools for analysis were used:

Descriptive statistic - measurements of central trend, row width, error rate.

Correlation analysis - relation of data.

T-test - mean value comparison in different conditions of the dependent variable.

\section{RESULTS}

Descriptive statistics of the compared methods in the studied group: Test sample 1 "Head Test" (Table 2).

\section{Identification of correlation between entry and exit "Head- test" results}

The statistical analysis of the compared methods in the 7-8 years age group confirms the described results and shows a significant increase of the total result of both parts of the test after implementation of logopedic therapy.

Significant increase of correctly done tasks from both sides of the test in our study can be explained by the neuropsychological basis of the processes related to increasing the efficacy of selective visual attention according to "response time" index typical for age 7-8 year olds.

Table 1. Distribution of the number of children during the years /2012-2017/ of the study

\begin{tabular}{|c|c|c|c|c|c|c|}
\hline Group & $\mathbf{2 0 1 2 / 2 0 1 3}$ & $\mathbf{2 0 1 3 / 2 0 1 4}$ & $\mathbf{2 0 1 4 / 2 0 1 5}$ & $\mathbf{2 0 1 5 / 2 0 1 6}$ & $\mathbf{2 0 1 6 / 2 0 1 7}$ & Total \\
\hline 7-8 y. & $\mathrm{n}=8$ & $\mathrm{n}=10$ & $\mathrm{n}=7$ & $\mathrm{n}=9$ & $\mathrm{n}=6$ & $\mathrm{n}=40$ \\
\hline
\end{tabular}

Table 2. Correlation between the entry and exit levels using "HEAD TEST" for the children subject to the study

\begin{tabular}{|l|c|c|c|c|}
\hline \multicolumn{1}{|c|}{ Methods } & Mean & Total & $\begin{array}{c}\text { Standard } \\
\text { deviation }\end{array}$ & $\begin{array}{c}\text { Standard error } \\
\text { of the mean }\end{array}$ \\
\hline Head 1entry & 7.1375 & 40 & 0.86963 & 0.13750 \\
\hline Head 1 exit & 7.5250 & 40 & 0.68827 & 0.10883 \\
\hline Head 1.2. entry & 5.9375 & 40 & 0.64239 & 0.10157 \\
\hline Head 1.2. exit & 6.5125 & 40 & 0.59364 & 0.09386 \\
\hline Headtotal entry & 13.075 & 40 & 0.68827 & 0.10883 \\
\hline Headtotal exit & 14.0375 & 40 & 0.77944 & 0.12324 \\
\hline
\end{tabular}


The results gathered after implementation of T- test for comparison of the mean value in different conditions of the dependent variable for the indicators in "Head test", represented in Table 3 after comparison, show significant difference in the two parts of the test study.

Those differences can be contributed to the fact that in the second part of the test (upon instruction) the children subjected to our study, 7-8 year olds have better level of formation of graphomotor skills.

\section{Test sample 2 - Dictation}

Table 4 represents percentage distribution of the types of mistakes on the different levels according to incidence rate at entry level. The results can be interpreted from the psychophysiological and neuropsychological model of initiation of the act of writing.

Underdevelopment of the complex manifestation of the visual-motor coordination in children with language deficits leads to difficulties in the already mentioned linguistic level.
Column "Others" encompasses a sum of punctuation mistakes and misspellings, poor level of literacy, lack of knowledge on graphemes. The percentage is relatively uniform in all linguistic levels.

Table 5 represents the percentage distribution of the types of mistakes on the different levels according to incidence rate at exit level after one year of logopedic therapy:

The results at exit level of the test study show positive influence of the therapeutic methods that we used. The difference of almost 20\% drop of the "rearrangements and merging/splitting on lexeme and syntaxeme level" shows that the age of 8 years in children with language deficits is crucial for the formation of normal language functions. It is important to point out also the drop of nearly $20 \%$ of phonetic and graphic replacements on phoneme, morpheme and lexeme levels.

Descriptive statistics of compared methods in Test 2 (Table 6).

Table 3. Results when using a T-test to compare the mean values under different conditions of the dependent variable on the indicators of the "Head Test"

\begin{tabular}{|c|c|c|c|c|c|c|c|}
\hline \multirow{2}{*}{ Head test } & \multirow{2}{*}{ Mean } & \multirow{2}{*}{$\begin{array}{l}\text { Standard } \\
\text { deviation }\end{array}$} & \multicolumn{2}{|c|}{ 95\% Confidence interval } & \multirow{2}{*}{$\mathrm{t}$} & \multirow{2}{*}{ total } & \multirow{2}{*}{ Significance } \\
\hline & & & Lowest & Highest & & & \\
\hline Entry 1- Exit 1 & -.38750 & .40012 & -.51546 & -.25954 & -6.125 & 40 & .000 \\
\hline Entry 1.2- Exit 1.2 & -.57500 & .52563 & -.74310 & -.40690 & -6.919 & 40 & .000 \\
\hline EntryTotal- ExitTotal & -6.51250 & .59364 & -6.70235 & -6.32265 & -9.384 & 40 & .000 \\
\hline
\end{tabular}

Table 4. Distribution of the types of errors by individual levels by frequency

in “Test sample 2 - auditory dictation", entry level - before starting therapy

\begin{tabular}{|l|c|c|c|c|c|c|c|c|}
\hline Types of mistakes & Errors & $\begin{array}{c}\text { Phonetic } \\
\text { replacements }\end{array}$ & $\begin{array}{c}\text { Graphic } \\
\text { replacements }\end{array}$ & Additions & Repetitions & $\begin{array}{c}\text { Rearran- } \\
\text { gements }\end{array}$ & $\begin{array}{c}\text { Merging } \\
\text { / Splitting }\end{array}$ & Others \\
\hline Phoneme level & $3.2 \%$ & $54.5 \%$ & $26.8 \%$ & $6 \%$ & - & - & - & $9.5 \%$ \\
\hline Morpheme level & $3 \%$ & $29.8 \%$ & $20.2 \%$ & $5.8 \%$ & $3.8 \%$ & $15.9 \%$ & $11.5 \%$ & $10 \%$ \\
\hline Lexeme level & $2.5 \%$ & $3.7 \%$ & $14.7 \%$ & $4.2 \%$ & $2 \%$ & $22.7 \%$ & $39.4 \%$ & $10.8 \%$ \\
\hline Syntaxeme level & $1 \%$ & $3.9 \%$ & $13.6 \%$ & $3.5 \%$ & $5.3 \%$ & $22 \%$ & $40.6 \%$ & $10.1 \%$ \\
\hline
\end{tabular}

Table 5. Distribution of the types of errors by individual levels by frequency

in "Test sample - 2 - auditory dictation", exit level-after one year of logopedic (speech) therapy

\begin{tabular}{|l|c|c|c|c|c|c|c|c|}
\hline Types of mistakes & Errors & $\begin{array}{c}\text { Phonetic } \\
\text { replacements }\end{array}$ & $\begin{array}{c}\text { Graphic } \\
\text { replacements }\end{array}$ & Additions & Repetitions & $\begin{array}{c}\text { Rearran- } \\
\text { gements }\end{array}$ & $\begin{array}{c}\text { Merging } \\
\text { /Splitting }\end{array}$ & Others \\
\hline Phoneme level & $3.2 \%$ & $54.5 \%$ & $26.8 \%$ & $6 \%$ & - & - & - & $9.5 \%$ \\
\hline Morpheme level & $3 \%$ & $29.8 \%$ & $20.2 \%$ & $5.8 \%$ & $3.8 \%$ & $15.9 \%$ & $11.5 \%$ & $10 \%$ \\
\hline Lexeme level & $2.5 \%$ & $3.7 \%$ & $14.7 \%$ & $4.2 \%$ & $2 \%$ & $22.7 \%$ & $39.4 \%$ & $10.8 \%$ \\
\hline Syntaxeme level & $1 \%$ & $3.9 \%$ & $13.6 \%$ & $3.5 \%$ & $5.3 \%$ & $22 \%$ & $40.6 \%$ & $10,1 \%$ \\
\hline
\end{tabular}

Table 6. Comparison of the results in "Sample test 2 - auditory dictation" - entry and exit levels

\begin{tabular}{|l|c|c|c|c|}
\hline \multicolumn{1}{|c|}{ Methods } & Mean & Total & Standard deviation & Standard error of the mean \\
\hline Test 2 entry & 14.9750 & 40 & 3.60546 & 0.57007 \\
\hline Test 2 exit & 19.5000 & 40 & 3.36650 & 0.53229 \\
\hline
\end{tabular}


Table 7. Results from "Test sample 2 - auditory dictation" using "T-test" entry and exit levels

\begin{tabular}{|l|c|c|c|}
\hline & Total & Correlation & Significance \\
\hline Test 2 entry\&Test 2 exit & 40 & 0.390 & 0.013 \\
\hline
\end{tabular}

Table 8. Results from "Test sample 2 - auditory dictation" at entry and exit levels on the three indicators

- the compared methods, correlation between entry and exit levels, comparison of the mean values

\begin{tabular}{|c|c|c|c|c|c|c|c|}
\hline \multirow{2}{*}{ Test 2 } & \multirow{2}{*}{ Mean } & \multirow{2}{*}{$\begin{array}{c}\text { Standard } \\
\text { deviation }\end{array}$} & \multicolumn{2}{|c|}{$\mathbf{9 5 \% \text { Confidence interval }}$} & \multirow{2}{*}{ t } & \multirow{2}{*}{ total } & \multirow{2}{*}{ Significance } \\
\cline { 4 - 5 } & & Lowest & Highest & & & \\
\hline EntryT2-ExitT2 & -4.52500 & 3.85631 & -5.75831 & -3.29169 & -7.421 & 40 & 0.000 \\
\hline
\end{tabular}

Identification of relation between entry and exit levels (Table 7).

$\mathrm{T}$-test for comparison of mean values in different conditions of the dependent variable according to the indicators in Test 2 (Table 8).

Also in the results of Test 2, showed in (Tables 6, $7,8)$ significant correlations were marked at entry and exit levels and in the three indicators- compared methods, relations between entry and exit levels, comparison of the mean values indifferent conditions of the dependent variable of the indicators.

\section{DISCUSSION}

Results show that the group of 7-8 years old children with language deficits is the sensitive moment which marks the start of formation with higher rate and maturation of structures of the left hemisphere: frontoparietal and basal temporal, responsible for development of spatial orientation and the ideomotor praxis. Hence the implementation of intensive logopedic therapy aimed for strengthening and development of the affected components related to visual- motor organization is crucial for developing graphomotor skills and establishing and development of the written form of language.

Similar data has been published by Machinskaya et al (7). Other authors who study the visual gnosis within children also describe the age of 7-8 years as crucial for maturation of the executive control and increasing of the activity of structures, responsible for the ventral visual system.(8-12). Our results also confirm the increased active attention and maturation of the visual gnosis within children in that particular age group.

The origin and existence of phonetic replacements in certain linguistic level can be attributed to deficits of different origin of auditory perception and articulation disorders. The presence of high percentage of phonetic replacements in dictation as well as splitting in writing, seen within words constituted by a lot of consonants strongly inappropriate and hard to be articulately combined, are described by other authors $(13,14)$.
Clinical studies of Bulgarian children with language deficits show that they have difficulty with: 1) perceptive tasks for differentiating phonemes in accordance to given feature (voiced/voiceless, sibilant/rustling sonority); 2) tasks for phonetic analysis as segmentation of phonemic numbers in words (quantitative sound analysis); defining the place of a given sound in words (quality sound analysis); separation of the first/last sound of words; discriminating different phonemes in paired words, that differ only by one word $(15,16)$. Phonological deficit is often associated with deficits in verbal memory and sometimes with difficulty in processing of purely verbal information according to instruction.

According to the data in English literature serious deficit in the area of morphology is observed in children with specific language disorders (17-20). Even though they manage to master the grammatical morphemes in consistency similar to that of normal children, language deficit children show an atypical types of control on those morphemes in time of production (15).

We believe that implementation of intensive logopedic therapy aimed for establishment and development of the deficient components related to visual- motor organization in this particular age is very important for development of graphomotor skills and formation and development of the written form of language.

\section{CONCLUSION}

The results of the implemented test samples in the age group of 7-8 years show that in children with language deficits this age period is sensitive for developing structures in left hemisphere and its frontal lobes, which are responsible for development of visual- motor coordination but also for establishment of verbal praxis, speech formation and perception.

The implemented therapeutic techniques in the period of logopedic therapy are aimed not only for establishing visual- special orientation but also for formation and development of language competence which is related to developing the written form of language. 


\section{Acknowledgment}

None.

Conflict of Interests: The authors declare that there are no conflicts of interest related to this article.

\section{Funding: None}

\section{Licensing}

This work is licensed under a Creative Commons Attribution 4.0 International (CC BY 4.0) License.

\section{Sažetak}

\section{GRAFOMOTORNE VEŠTINE DECE SA JEZIČKIM DEFICITOM U OSNOVNOŠKOLSKOM UZRASTU - FORMIRANJE I RAZVOJ}

\section{Spassova Kalinka}

Medical University Varna Prof. Dr Paraskev Stoyanov - Faculty of Public Health, Varna, Bulgaria

Uvod: Formiranje grafomotornih veština kod dece sa jezičkim deficitom, u osnovnoj školi, je težak i dug proces, a njegovo narušavanje dovodi do ozbiljnih problema ne samo sa procesom opismenjavanja, već i do narušavanja akademskog usavršavanja.

Cilj: Cilj naše studije je da pokažemo stepen formiranja grafomotrnih veština kod dece sa jezičkim deficitom, u osnovnoškolskom uzrastu, pre i nakon implementacije sistema terapeutskih tehni$\mathrm{ka}$, pristupa i metoda baziranih na svetskom i bugarskom iskustvu na polju lečenja poremećaja grafomotornih veština.

Materijal i Metode: Studijom je obuhvaćeno ukupno 40 dece u osnovnoj školi, uzrasta 7-8 godina, koja su bila podvrgnuta logopedskoj terapiji u cilju prevazilaženja poteškoća sa grafomotornim veštinama. Sprovodila se tokom perioda od 5 godina.

\section{REFERENCES}

1. Raichev R, Raicheva M, Rasheva M, Matanova M, Stoyanova K, Raichev I. Neuropsychology. Basis of neuropsychology. Sofia: ARTIK-2001, 2012.

2. Mavlov L. Fundamental neurology. Sofia: Boyko Stamenov, 2000.

3. Peicheva, S. Cognitive neurosychology. Sofia: Veda Slovena JG, 2000.

4. Roux FE, Draper L, Kopke B, Demonet JF. Who actually read Exner? Returning to the source of the frontal "writing centre" hypothesis. Cortex. 2010; 46(9): 1204-10.

5. World Health Organization. International Statistical Classification of Diseases and Related Health Problems. Tenth Revision. 2003. https://apps.who.int/iris/bitstream/handle/10665/ 42980/9241546530_eng.pdf? sequence=1.

6. Yakimova P. Disorders in written language, Part 1: Disorders in writing. Sofia: Romel, 2009: 74-6.

7. Machinskaya RI, Krupskaya EV. Maturation of the regulatory structuresof the brain and the organization of attention in children of primary school age. Vestnik neirologi i psihiatrii i neirohirurgii. 2011; (4): 32-43.
Terapija se sprovodila individualno ili u grupi sa dvoje dece.

Rezultati: Podaci sa testa $1 \mathrm{i}$ testa 2 pokazuju razvoj i maturaciju struktura leve hemisfere mozga: frontoparijetalne i bazalno-temporalne, odgovornih za prostornu orjentaciju i idemotornu apraksiju. Iz tog razloga, grupa uzrasta 7-8 godina se može smatrati razumnom za razvoj grafomotornih veština kao komponente razvoja pisanog jezika i posebno je pogodna za intenzivnu logopedsku terapiju čiji je cilj njen razvoj.

Zaključak: Primenjene terapeutske tehnike tokom logopedske terapije nisu usmerene samo na uspostavljanje okulo-prostorne orijentacije, već i na formiranje i razvoj jezičke kompetencije, koje su direktno povezane sa formiranjem pisanog jezika.

Ključne reči: grafomotrne veštine, frontoparijetalne strukture, ideomotrna apraksija.

8. Cycowicz YM. Memory development and event-related brain potentials in children. Biological psychology. 2000; 5(4): $145-74$.

9. Dukette D, Stiles J. The effects of stimulus density on children's analysis of hierarchical patterns. Developmental science. 2001; 4(2): 233-51.

10. Farber DA, Petrenko NE. Individual peculiarities of visual recognition in children of preschoool age.Almanah novuie issledovaniya. 2012; 1(30): 31-4.

11. Jolly C, Gentaz E. Analysis of cursive letters, syllables, and words handwriting in a French second-grade child with developmental coordination disorder and comparison with typically developing children. Frontiers in Psychology. 2013; 4(1022): 1-22.

12. Oliveira RE, Billington J, Wann JP. Optimal use of visual information in adolescents with developmental coordination disorder. Experimental Brain Research. 2014; 232(9): 2989-95.

13. Jekov J. Predictors of early diagnosis of dysgraphia in preschool ad primary school age. Dissertation. Shumen. 2010.

14. Richards TL, Grabowski P, Boord TJ, Yagle K, Askren $\mathrm{M}$, Mestre Z.et al. Contrasting brain patterns of writing-related DTI parameters, fMRI connectivity, and DTI-fMRI connectiv- 
ity correlations in children with and without dysgraphia or dyslexia. NeuroImage Clin. 2015; 28(8): 408-21.

15. Todorova E. Dyslexia.Sofia: New Bulgarian University Press, 2007.

16. Shtereva K. Structure of phonologic maturation in bulgarian children. Psychological studies. BAS. Sofia. 2012; 1:25-36.

17. Sela I, Karni A. Differences in learning volitional (manual) and nonvolitional (posture) aspects of a complex motor skill in young adult dyslexic and skilled readers. PLOS On E. 2012; 7(9): e43488. doi: 10.1371/journal.pone.0043488.
18. Sturm JM, Rankin-Erikson JL. Effects of hand-drawn and computer-generated concept mapping on the expository writing of middle school students with learning disabilities. Learning disabilities practice. 2002; 17(2): 124-39.

19. Stoeckel RE, Colligan RC, Barbaresi WJ, Weaver AL, Killian JM, Katusic SK. Early speech-language impairment and risk for written language disorder: a population-based study. J Dev Behav Pediatr. 2013; 34(1): 38-44.

20. Visscher C, Houwen S, Scherder EJ, Moolenaar B, Hartman E. Motor profile of children with developmental speech and language disorders. Pediatrics. 2007; 120(1): e158-63.

\section{Correspondence to/Autor za korespondenciju}

Ass. Prof. Kalinka Spassova Ivanova, PhD

Medical University - Varna

"Prof. Paraskev Stoyanov", 55 Marin Drinov str., 9002 Varna, Bulgaria

Faculty of Public Health, Department of Speech Therapy and Medical Pedagogics

email: spasova.kalina@abv.bg

phone: +359892232800 